\title{
IJPHN
}

\section{Body Weight Prediction Model using Mid Upper Arm Circumferences and Knee Height in Adult}

\author{
Katherina $^{1}$, Trini Sudiarti ${ }^{2}$ \\ ${ }^{1}$ Undergraduate Student of Public Health Nutrition Department, Universitas Indonesia, Depok, West Java, \\ Indonesia \\ ${ }^{2}$ Depatment of Public Health Nutrition, Faculty of Public Health Universitas Indonesia, F Building $2^{\text {nd }}$ \\ Floor Kampus Baru UI Depok 16424, Indonesia \\ Corresponding author: trini.sudiarti@gmail.com
}

\begin{abstract}
Bodyweight is one of the most common anthropometric components to determine a prescription for diet and drugs. However, this way proved to be a challenge for individuals who are unconscious and or have disabilities. The present study aims to derive a simple equation to estimate the bodyweight of adults in Jakarta by using a cross-sectional study on data taken with simple random sample method. Measurements of body weight (BW), the mid-upper arm circu mfe rence (MUAC), and the knee height (KH) were done in 164 adults in South Jakarta in May 2017. The resulting equation, which is derived by multi linear regression, is: $\mathrm{BW}=2.8 * \mathrm{MUAC}+1.2 * \mathrm{KH}-1.25 * \mathrm{Z}-75.1$ ( $\mathrm{R}$-square 0.841 ; $\mathrm{p}$-value $<0.001$ ), with $\mathrm{Z}$ value of 1 for female and 2 for male. The equation can approximate the bodyweight of adults.
\end{abstract}

Keywords: Adults, anthropometry, body weight, knee height, middle-upper arm circumference

\begin{abstract}
Abstrak
Berat badan merupakan salah satu komponen antropometri yang paling banyak digunakan untuk menentukan preskripsi diet dan preskripsi obat pasien. Namun terkadang pengukuran berat badan tidak dapat dilakukan secara langsung, seperti pada individu penyandang disabilitas dan kesadaran lemah. Penelitian ini bertujuan untuk mengembangkan rumus sederhana dalam memprediksi berat badan pada orang dewasa menggunakan metode studi potong lintang dan subyek dipilih secara acak sederhana. Pengukuran berat badan, lingkar lengan atas dan tinggi lutut dilakukan terhadap 164 orang dewasa (20 59 tahun) di Kedeputian Ilmu Pengetahuan Sosial dan Kemanusiaan Lembaga Ilmu Pengetahuan Indonesia, Jakarta Selatan pada bulan Mei 2017. Model prediksi berat badan akhir yang diperoleh menggunakan analisis regresi linear ganda adalah: Berat Badan estimasi $(k g)=2,8 * L i L A+1,2 * T L-$ $1,25 * Z-75,1$ ( $R$-square 0,841; p-value <0,001), nilai $Z=1$ untuk perempuan dan 2 untuk laki-laki. Persamaan hasil penelitian mampu memprediksi berat badan dan dapat digunakan pada orang dewasa .
\end{abstract}

Kata kunci: Antropometri, berat badan, dewasa, lingkarlengan atas, tinggi lutut

\section{Introduction}

Body weight measurement is one of the most essential anthropometric components for various purposes. Bodyweight is considered an indicator of the physical aspect and used as an indicator of a person's health condition in many cases (1). Bodyweight measurements widely used to calculate body mass index (BMI), which is an indicator to determine a person's nutritional status. Furthermore, bodyweight is the best anthropometric measurement for detecting malnutrition (2). Losing more than $5 \%$ of normal body weight could underlie the risk of moderate malnutrition and losing more than $10 \%$ indicates a high risk of malnutrition (3).

When measuring body weight, the position of the subject must stand upright, both hands straight at the sides of the body, and eyes straight ahead to obtain the right number of the measurement 
results (4). However, in some conditions such as persons with disabilities and patients with loss of consciousness, actual body weight is difficult to measure using standard measurement tools and methods (5-7). The number of people with disabilities in Indonesia according to the National Basic Health Research (Riskesdas) in 2013 was $11 \%$, with prevalence of difficulty standing and walking respectively $5.8 \%$ and $6.8 \%$. Based on the research, disability prevalence in the adult group aged 15-24 years, 25-34 years and 35-44 years were $7.1 \%, 7.9 \%$ and $10.9 \%$ respectively (8).

Individuals with disabilities and weak or losing consciousness need equipment and technological solutions which could meet body weight measurement standards, such as bed scales and chair scales $(2,9)$. Nonetheless, only a few of institutions provides adequate standard equipment for weighing patients with these conditions or the scales available are often not calibrated. In addition, adequate equipment such as bed scales and chair scales requires high costs and not all healthcare facilities are able to provide them $(2,6,7)$.

Many other alternative methods have been researched and developed to obtain accurate body weight data, namely through the replacement of anthropometric measurements on other body parts (surrogate measurement). The most commonly used anthropometric index as a predictor of body weight includes mid-upper arm circumference, knee height, calf circumference, waist circumference, hip circumference, and subscapular skin thickness (9-15).

Determination of body weight through surrogate measurement, especially anthropometric index such as the skin fold thickness requires a highly trained person to get a valid number. Then, other anthropometric index such as hip and waist circumference are very impractical to do with individuals with physical limitations such as persons with disabilities and patients with weak or losing consciousness, especially patients who come in an emergency condition (16). Mid-upper arm circumference is the best predictor for both men and women to predict body weight. Adding high variables to the equation could increase the predictive capacity for both men and women. The combination of mid-upper arm circumference with height is the best prediction model for estimating body weight in patients who is impractical to be weighed (9). Moreover, knee height could be used to estimate height and weight. Research conducted by Rodriguez et al. showed that there is a good correlation between height and knee height. Bernal-Orozco et al. conducted a study of elderly women in Mexico finding that knee height had a strong correlation in predicting body weight (17). Other studies in the elderly in Hong Kong also found the same results, knee height has a good correlation with body weight and is the biggest coefficient in the body weight prediction formula (18).

Many studies of body weight prediction models using a combination of anthropometric measurements have been commonly carried out in various parts of the world on the sick and elders. However, prediction models in one age group in one place would not be suitable for use in another place with the same age group (13). This study was conducted considering the importance of body weight measurement, which is an assessment indicator of various medical procedures, and the limitations of many adult patients to weigh their body weight, especially in Indonesia which has a high disability number. The aim of this study was to predict a weight measurement model using an anthropometric index of adult's mid-upper arm circumference and 
knee height at the Deputy for Social Sciences and Humanities in Indonesia's Institute of Sciences (IPSK LIPI) Jakarta. Additionally, because of the high accessibility of measurement variables, this could be used by people with disabilities and patients with weak or losing consciousness. Furthermore, IPSK LIPI subjects meet the inclusion criteria needed in making prediction models.

\section{Methods}

This research is a quantitative research with observational approach using cross-sectional design. As independent variables, particularly mid-upper arm circumference, knee height, age, and gender and the dependent variable is actual body weight. This research was conducted at the IPSK LIPI office during May 2017. The target population of the study was all employees of the adult age category at IPSK LIPI. The sample in this study were subjects who met the inclusion and exclusion criteria. The inclusion criteria are: (a) IPSK LIPI's active employees in 2017; (b) Aged 20-59 years; (c) actual body weight can be weighed; and (d) willing to participate in this research. While the exclusion criteria are: (a) having edema; (b) abnormalities in the leg bones (fractures) or unable to move the feet, by observation of the feet; (c) people with disabilities; (d) is pregnant. Based on the calculation of the sample size using the sample size formula of the hypothesis test of correlation coefficient and 2 different independent with $\alpha=0.05$ and $\beta=90 \%$, obtained a minimum sample size of 164 people. The sampling method is simple random sampling (19).

In the series of data collection process, the researchers included three students of the Nutritional Sciences of the Universitas Indonesia as enumerators who assisted in anthropometric measurements of body weight, mid-upper arm circumference and knee height. Enumerators have been trained before the data collection process took place, with the purpose of having mutual understanding and practicing anthropometric measurement skills. The enumerator selection was conducted using a measurement test of the candidate with the average measurement results as the point of justification. The enumerators chosen in the study are those whose measurement results are close to the researchers measurement results as the golden standard.

The body weight measurement instrument uses a digital scale Omron $\mathrm{HN}-283$ accuracy of $0.1 \mathrm{~kg}$. Mid-upper arm circumference was measured with a fiberglass tape of $0.1 \mathrm{~cm}$ accuracy. A wooden caliper with an accuracy of 0.1 $\mathrm{cm}$ is used to measure knee height. The respondent characteristic questionnaire was used to obtain data on age and sex. All anthropometric measurement instruments are calibrated before use. To ensure the accuracy of the instrument, the device was calibrated after every 10 measurements. Data used was the sum average of the two measurements measured on each subject. Should there be huge discrepancies between the two measurements, a third measurement was collected and the two closest measurements were to be sum averaged.

The statistical analysis includes univariate, bivariate and multivariate. Univariate analysis aims to describe the dependent and independent variables with frequency or distribution values. The aim of bivariate analysis is to determine the relationship between the two variables using simple linear regression correlation test and independent t-test. Multivariate analysis uses multiple linear regression analysis to connect between the dependent variables with several numerical independent variables. The bivariate selection process 
and multivariate modeling are carried out before producing the final prediction model.

An ethical clearance No. 160/UN2.F10/PPM.00.02/2017 was issued by the Community Research and Engagement Ethics Committee of the Faculty of Public Health of the Universitas Indonesia on the paper. Additionally, data collection was only done to research subjects who had signed informed consents.

\section{Results}

Table 1 shows the proportion of male subjects $(51.2 \%)$ is greater than female subjects (48.8\%). The age group 20-29 has the biggest proportion $(34.7 \%)$ and the age group 40-49 has the smallest proportion (12.8\%) compared to other age groups. Table 2 presents the average age of respondents $34.5 \pm 12.59$ years with an age range of 20-59 years, body weight $64.6 \pm 12.62 \mathrm{~kg}$, mid-upper arm circumference $30.4 \pm 3.73 \mathrm{~cm}$ and knee height $490 \pm 2.96 \mathrm{~cm}$. The average of body weight, mid-upper arm circumference, and knee height of male subjects were greater than women, but the average age of female subjects was higher than male subjects.

Based on the independent t-test. there were significant differences in the average body weight between male and female subjects with a $p$-value of 0.000 (Table 3).

The intercept and slope values that will be used to make the equation are presented in Table 4. The body weight regression equation obtained using the mid-upper arm circumference (R1), knee height (R2), and sex (R3) variables are formulated sequentially in the following equation:

$$
\begin{array}{r}
\text { Body weight }(\mathrm{kg})=-21.523+2.913 \text { MUAC } \\
(\mathrm{R} 1) \\
\text { Body weight }(\mathrm{kg})=-20.747+1.761 \mathrm{KH} \\
(\mathrm{R} 2) \\
\text { Body weight }(\mathrm{kg})=58.053+0.200 \mathrm{~S}
\end{array}
$$

Multiple linear regression analysis starts from the bivariate selection process followed by multivariate modeling and linear regression assumption test. Bivariate selection results showed all variables of gender. age. mid-upper arm circumference. and knee height entered into the multivariate modeling because it had a $p$-value of $<0.25$. The multivariate modeling process uses the backward method and the reduce model. The results of the model are followed by a linear regression assumption test in the form of existence assumption. independence assumption. linearity assumption. homoscedascity assumption. normality assumption and multi-collinearity diagnostic test. The final prediction model resulting from this study fulfills all stages of the bivariate selection test. multivariate modeling and the linear regression assumption test. The following is a regression equation generated based on multivariate analysis:

$$
\begin{array}{r}
\text { Body Weight }(\mathrm{kg})= \\
(2.8 \times \mathrm{MUAC})+(1.2 \times \mathrm{KH})-(1.25 \times \mathrm{S})-75.1
\end{array}
$$

note:

MUAC $=$ Mid-Upper Arm Circumference $(\mathrm{cm})$

$\mathrm{KH}=$ Knee Height $(\mathrm{cm})$

$\mathrm{S}=$ Sex (Male 1, Female 2) 
Table 1. Proportion of respondent's age according to sex

\begin{tabular}{cccc}
\hline Age Group & $\begin{array}{c}\text { Male } \\
\mathrm{n}(\%)\end{array}$ & $\begin{array}{c}\text { Female } \\
\mathrm{n}(\%)\end{array}$ & $\begin{array}{c}\text { Total } \\
\mathrm{N}(\%)\end{array}$ \\
\hline $20-29$ & $28(17.1)$ & $29(17.6)$ & $57(34.7 \%)$ \\
$30-39$ & $23(14.0)$ & $14(8.5)$ & $37(22.5 \%)$ \\
$40-49$ & $13(7.9)$ & $8(4.9)$ & $21(12.8 \%)$ \\
$50-59$ & $20(12.2)$ & $29(17.8)$ & $49(30.0 \%)$ \\
\hline Total & $84(51.2 \%)$ & $80(48.8 \%)$ & $164(100 \%)$ \\
\hline
\end{tabular}

Table 2. Distribution of respondents according to gender, age, body weight, mid-upper arms circumference, and knee height

\begin{tabular}{ccccccc}
\hline Variabel & $\mathrm{N}$ & Mean & Median & SD & Min-Max & $95 \%$ CI Mean \\
\hline Age (year) & 164 & 38.40 & 34.50 & 12.59 & $20-59$ & $36.46-40.34$ \\
Male & 84 & 37.38 & 33.50 & 12.08 & $20-59$ & $34.76-40.00$ \\
Female & 80 & 39.46 & 35.50 & 13.09 & $21-59$ & $36.55-42.38$ \\
Weight $(\mathrm{kg})$ & 164 & 65.74 & 64.60 & 12.62 & $41.30-99.20$ & $63.79-67.68$ \\
$\quad$ Male & 84 & 69.29 & 68.80 & 12.73 & $48.40-99.20$ & $66.53-72.05$ \\
Female & 80 & 62.00 & 61.40 & 11.43 & $41.30-97.20$ & $59.46-64.55$ \\
MUAC (cm) & 164 & 29.96 & 30.40 & 3.73 & $21.50-39.50$ & $29.38-30.54$ \\
$\quad$ Male & 84 & 30.31 & 30.50 & 3.57 & $22.40-38.00$ & $29.54-31.09$ \\
Female & 80 & 29.59 & 29.75 & 3.88 & $21.50-39.50$ & $28.72-30.45$ \\
Knee Height (cm) & 164 & 49.11 & 49.00 & 2.96 & $39.00-56.00$ & $48.65-49.56$ \\
$\quad$ Male & 84 & 50.73 & 51.00 & 2.66 & $39.00-56.00$ & $50.15-51.30$ \\
Female & 80 & 47.41 & 47.45 & 2.21 & $39.00-53.20$ & $46.92-47.90$ \\
\hline
\end{tabular}

Table 3. Differences in average body weight according to sex*

\begin{tabular}{|c|c|c|c|c|c|c|}
\hline Sex & n & Mean (kg) & SD & $\overline{\text { SE }}$ & p-value & $95 \%$ CI \\
\hline Male & 84 & 69.29 & 12.73 & 1.39 & $0.000 * *$ & 3,56 \\
\hline Female & 80 & 62.00 & 11.43 & 1.28 & 0.000 & $5.50-11.01$ \\
\hline
\end{tabular}

Table 4. Correlation and simple linear regression of body weight with mid-upper arm circumference. knee height and age

\begin{tabular}{ccccccc}
\hline & $\mathrm{n}$ & $\mathrm{p}$-value & $R$ & $\mathrm{R}$ square & Intercept & Slope \\
\hline MUAC & & & & & & \\
Male & 84 & 0.000 & 0.874 & 0.763 & -25.009 & 3.111 \\
Female & 80 & 0.000 & 0.886 & 0.784 & -15.121 & 2.607 \\
Sub-Total & 164 & 0.000 & 0.862 & 0.743 & -21.523 & 2.913 \\
Knee Height & & & & & & \\
Male & 84 & 0.008 & 0.287 & 0.082 & -25.262 & 1.371 \\
Female & 80 & 0.001 & 0.357 & 0.128 & -25.564 & 1.847 \\
Sub-Total & 164 & 0.000 & 0.413 & 0.170 & -20.747 & 1.761 \\
Sex & & & & & & \\
Male & 84 & 0.070 & 0.199 & 0.039 & 61.648 & 0.209 \\
Female & 80 & 0.013 & 0.275 & 0.076 & 52.515 & 0.240 \\
Sub-Total & 164 & 0.010 & 0.200 & 0.040 & 58.053 & 0.200 \\
\hline
\end{tabular}




\section{Discussion}

While another study conducted in Florianópolis, Brazil done to hospitalized adults by Melo et al. showed a higher average body weight compared to the study conducted in Central Jakarta, Indonesia by Arupah (7, 20). Hence, there exists discrepancies in body weight between people living in different cities. The differences are possible due to body weight influenced by a combination of several factors. including genetics, ethnics, environmental, and other interactions $(21,26)$. The result of this study showed that the average body weight of all subjects was higher than the results conducted by Arupah (20). The average weight of adults in South Jakarta in 2017 is $65.74 \pm 12.62 \mathrm{~kg}$. while the average body weight of adults in Central Jakarta in 2002 was $60.32 \pm 9.29 \mathrm{~kg}$ according to Arupah (20). The average mid-upper arm circumference in this study was $29.96 \pm 3.73 \mathrm{~cm}$. presenting a slightly higher value compared to the result from the study conducted by

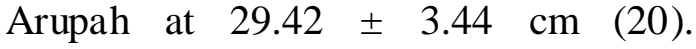
Additionally, the result of another study conducted in Thailand by Chittawatanarat et al showed a higher result with an average mid-upper arm circumference $28.96 \pm 3.29 \mathrm{~cm}$ (22). The difference in the average size of the mid-upper arm circumference could occur due to differences mentioned above. is known there are three categories of body figure or, namely ectomorphic, mesomorphic, and endomorphic. Individuals who are likely to have mesomorphic and endomorphic body shape will have a higher upper arm circumference compared to individuals with ectomorphic shape (20).

The results of the average knee height of respondents in this study was $49.11 \pm 2.96 \mathrm{~cm}$. which were lower than the average knee height of the study in Depok conducted by Paramita at $49.61 \pm$ $2.36 \mathrm{~cm}(23)$. The average knee height in Central Jakarta was the lowest at $47.61 \pm$ $2.70 \mathrm{~cm}(20)$. The discrepancies indicate there are indeed differences in anthropometric size of knee height between different cities. The differences are possible due to body weight influenced by a combination of several factors, including genetics. ethnics. environmental. and other interactions (18).

Out of 164 research subjects 84 $(52.1 \%)$ were male, with $80(47.9 \%)$ were female. The relationship between body weight and sex after an independent t-test provided information that male and female body weights was significantly different. The difference in average weight between male and female subjects were as high as $8.69 \mathrm{~kg}$. This proved that there are differences in weight gain and development between the 2 sexes. Differences in body composition and types of physical activity between men and women could possibly result in the difference in energy requirements between the sexes (24). Female have more fat deposits, but less muscle tissue. These conditions cause an increase in the amount of fat in subcutaneous tissue. As a result, the percentage of fat in subcutaneous tissue on the skin of a female's body is considered to be greater than that of men. Male have bigger muscles than female and muscle has a higher density than fat. Therefore. male generally have a greater weight than female (26).

Mid-upper arm circumference was strongly correlated with the body weight in this study. These results showed that the correlation coefficient values in male, female and both sex as respectively by $0.874 ; 0.886$; and 0.862 . Hence, mid-upper arm circumference 
served as a good indicator for estimating body weight. Furthermore, the strong correlation between mid-upper arm circumference and body weight might possibly be explained from the components measured in the measurement of mid-upper arm circumference including skin, fat, muscle, and bone components. The more fat stored in one's body would affect its size. Excessive fat accumulation would cause the size of the mid-upper arm circumference to be widening, so that the measure ment of upper arm circumference is considered to represent the current weight condition (26). This is in line with Jellife's statement that mid-upper arm circumference has a high level of sensitivity to changes in body weight. otherwise arm circumference will shrink along with the occurrence of weight loss (25).

The results showed that knee height and body weight were moderately correlated. with coefficients for male, female, and both sexes of $0.287 ; 0.357$; and 0.413. Knee height has a strong correlation with height and could be used as an anthropometric measure to estimate height in adult individuals after the age of 5 (24). Height growth typically stops at the age of 18 years old for female. and 20 years old for male. The peak of height growth female commonly occurs at the age of 10.5 years old along with a peak height growth in the knee. whereas in male the peak height growth occurs at 13.75 years old but the peak growth in knee height occurs earlier at the age of 12.5 years old (27). Thus. the use of knee height to estimate weight in adults should have been reliable. A study conducted by Chittawatanarat et al showed that knee height had a positive correlation with body weight. henceserving as one of the more reliable variables estimate body weight (22).
The model in this study was derived from the sum average of several measurement of body weights done in the. The correlation between the actual body weight and the derived model was $0.917(p$-value $=0.000)$ with value difference of $0.004 \mathrm{~kg}$. $0.004 \mathrm{~kg}$. and $0.005 \mathrm{~kg}$ for male. female. and both sexes accordingly. Hence. it was concluded that it was possible to estimate one's body weight with mid-upper arm circumference. knee height. and gender. The results of this study are in line with Arupah and Kamaluddin's research which found that the estimation model used variables such as mid-upper arm circumference and knee height $(2,28)$.

The body weight prediction model using mid-upper arm circumference and knee height could serve as an accurate. alternative measurement and could be applied to obtain weight data for people with disabilities as well as coma patients. It is worth noting that the correlation coefficient between body weight and mid-upper arm circumference was 0.862 $(p$-value $=0.000)$ indicating that mid-upper arm circumference had a strong correlation with body weight. The difference in the correlation coefficient value between themodel using mid-upper arm circumference and knee height using only upper arm circumference was only 0.055 . Taking into account the short time required to measure the variables as well as the reliability of the. application of this model is highly recommended. That said. in order to gain accurate estimations. proper measurement procedures are required suggesting the need of training.

\section{Conclusion}

The derived model in this study based on mid-upper arm circumference and knee height has a high level of accuracy when proper measurements of 
mid-upper arm circumference and knee height are to be done. Additionally, if there be a constraint during real-life application. mid-upper arm circumference alone should help to estimate one's body weight.

\section{Acknowledgement}

The authors would like to express their gratitude to the directors of IPSK LIPI who have allowed the study to be conducted as well as employees of the institution who have participated in the study.

\section{References}

1. Veraldo C. Dugelay J. Weight Estimation from Visual Body Appearance. Eurocom :France; 2010.

2. Barceló M. Torres O. Mascaró J. Francia E. Cardona D. Ruiz D. Assessing nutritional status in elderly; evaluation of Chumlea's equations for weight. Nutr Hosp. 2013; 28(2):314-318.

3. Reyes JG. Zuniga AS. Cruz MG. Prevalence of hyponutrition in the elderly at admission to the hospital. Nutr Hosp. 2007; 22: 702-9.

4. CDC. (2016). National Health and Nutrition Examination Survey (NHANES). Anthropometry Procedures Manual. (online). Available at: https://www.cdc.gov/nchs/data/nhane s/nhanes 15 16/2016_Anthropometr y_Procedures_Manual.pdf

5. Darnis S. Fareau C. Corallo CE. Poole S. Dooley MJ. Cheng AC. Estimation of body weight in hospitalized patients. QJM. 2012;105 (8): 769-74.

6. Quiroz-Olguin et al. Validation of a new formula for predicting body weight in a Mexican population with overweight and obesity. Nutrition hospitalaria: Organo official de la Sociedad Expance de Nutrition Parenteral Y Enteral. 2013; 28(3): 690-693.

7. Melo APF. Salles RK. Vieira FGK. Ferreira MG (2014). Methods for Estimating Body Weight and Height in Hospitalized Adults: A Comparative Analysis. RBCDH. Universidade Federal dr Santa Catarina: Brasil; 2014.

8. Kementerian Kesehatan RI. Info DATIN Situasi Gizi di Indonesia. Pusat Data dan Informasi Kementerian Kesehatan RI: Jakarta; 2013.

9. Chumlea WC. Guo S. Roche AF. Steinbaugh ML. Prediction of body weight for the nonambulatory elderly from anthropometry. J Am Diet Assoc. 1988; 88 (5): 564-568.

10. Ross Laboratories. The Ross Knee Height Caliper. 2002. (online). Available at: http://ip.com/pdf/ipcompad/IPCOM0 00006911D.pdf

11. Rabito E. Mialich M. Martínez E. García R. Jordao A. Marchini J. Validation of predictive equations for weight and height using a metric tape. Nutrición Hospitalaria. 2008;23(6):614-618.

12. Lorenz M. Graf M. Henke C. Hermans M. Ziemann U. Sitzer M et al. Anthropometric approximation of body weight in unresponsive stroke patients. Journal of Neurology. Neurosurgery \& Psychiatry. 2007;78(12):1331-1336.

13. Bernal-Orozco MF. Vizmanos B. Hunot C. Flores-Castro M. Leal-Mora D. Cells A et al. Equation to estimate body weight in elderly Mexican women using antropometric measurement. Nutr Hosp. 2010; 25(4) : 648.655.

14. Narancic NS. Milicic J. Tomas Z. Petranovic MZ. Skaric-Juric T. 
Tomek-Roksandic S. (2013). Anthropometric indices of nutritional status in Croatian oldest old: new equations to predict height and weight. Periodicum Biologorum. 2013; 115 (4): 483-489.

15. Philip JA. Zacharia IP. Paul SS. Bhatt AN. Estimating height and weight in old-age from other anthropometric measurements - A Community based cross-sectional study from Central Kerala. Int J Med Sci Public Health. 2017; 6:426-428.

16. Cattermole GN. Graham CA. Rainer TH. Mid-arm circumference can be used to estimate weight of adult and adolescent patients. Emerg Med J Published. 2016.

17. Rodriguez MP. Tanchoco CC. Duante DA. Cea EE. Aquino MGC. Validation on the use of arm span and knee height as proxy indicators of height among normal and mobility-impared children. 2004.

18. Jung MY. Chan MS. Chow VS. et al. Estimating geriatric patient's body weight using the knee height caliper and mid-arm circumference in Hong Kong Chinese. Asia Pac J Clin Nutr. 2004;13(3):261-264.

19. Lemeshow S. Hosmer JrDW. Klar J. Lwanga SK. (1990). Adequacy of Sample Size in Health Studies. WHO: England.

20. Arupah. (2002). ModelPrediksi Berat Badan Menggunakan Predictor Lingkar Lengan Atas dan Tinggi Lutut pada Orang Dewasa di Jakarta tahun 2002. (Skripsi). Depok: Fakultas Kesehatan Masyarakat. 2002.

21. Lee. Nieman DC. (2010). Nutritional Assessment. Ed 5. McGraw-Hill: New York. 2010.

22. Chittawatanarat K. Pruenglampoo S. Trakulhoon V. Ungpinitpong W. Patumanond J. (2012). Development of gender and age group-specific equations for estimating body weight from anthropometric measurement in Thai adults. International Journal of General Medicine. 2012; 5: 65-69.

23. Paramita AP. Model Prediksi Tinggi Badan pada Kelompok Dewasa Muda dengan Prediktor Tinggi Lutut di FKM UI Tahun 2012 (Skripsi\}. Depok: Fakultas Kesehatan Masyarakat Universitas Indonesia.

24. Gibson. Rosalind S. (2005). Principles of Nutritional Assessment. 2nd Ed. New York: Oxford University Press. Inc.

25. Cattermelo GN. Graham CA. Rainer TH. Mid-arm circumference can be used to estimate weight of adult and adolecents patients. Emerg Med J. 2017; 34(4):23-236.

26. Gropper S. Smith J. Advanced nutrition and human metabolism. 6th ed. Belmont: Cengage Learning; 2013.

27. Cameron N. Bogin B. Human Growth and Development. London: Academic Press; 2013

28. Kamaluddin. M. Model Prediksi Berat Badan Menggunakan Prediktor Lingkar Lengan Atas dan Tinggi Lutut pada Remaja Usia 14-18 Tahun di SMA Budi Mulia Kota Bogor Tahun 2016. (Skripsi). Depok: Fakultas Kesehatan Masyarakat Universitas Indonesia.2016. 